\title{
DIFFERENTIATION OF THE SOCIAL SITUATION IN EUROPEAN POST-COMMUNIST COUNTRIES
}

\author{
Tomasz Michalski, Tomasz Wiskulski
}

\begin{abstract}
After 1989, the countries today called post-communist began a tedious process of systemic transformation. Its result is progressive differentiation of the situation in them. The aim of the study is to analyse social differentiation in these countries. This was done in three dimensions based on 6 indicators: civil liberties (World Press Freedom Index, Doing Business ranking), wealth, but depicted more comprehensively than just in economic terms (Legatum Prosperity Index, Social Progress Index), gender/sexual equality (Gender Development Index, Human Rights Situation of LGBTI). In the course of analysis, it was found that the best situation prevails in the countries which are currently members of the European Union (except for Lithuania, Bulgaria, and Romania) and the worst one is in the countries of the Commonwealth of Independent States plus Albania and Macedonia.
\end{abstract}

Keywords: civil liberties, gender/sexual equality, post-communist countries, social situation, wealth

\section{Introduction}

After 1989 societies of the countries formerly called "people's democracy" began an arduous process of reforms which is multifaceted and can be described in many ways (von Beyme, 1996; Havrylyshyn, 2007; Janušauskienė, 2008; Kollmorgen, 2013; Norkus, 2012).

The result of the systemic transformation process is far-reaching diversity of these countries, or differentiation that can be seen in many aspects. One of them is the differentiation between the social situation of their populations. Hence, the main objective of the study is to show regularities in differentiation of the social situation of European post-Communist countries. In order to achieve this objective, the social situation was analysed in three dimensions:

1. Civil liberties. In this case, both political and economic freedom was taken into account. To evaluate the former, the World Press Freedom Index was used (Giannone, De Frutos, 2016; Nouinou et al., 2015); for the latter - Doing Business (Bednarova, Laboutkova, 2013; PinheiroAlves, Zambujal-Oliveira, 2012). The World Press Freedom Index is an indicator of a qualitative and quantitative nature. It has a destimulant character and takes values from 0 to 100: individual countries are ranked 
an such a way that 0 is given to the country with the best analysed situation. Doing Business presents quantitative indicators concerning business regulations as well as property rights protection. Doing Business measures 11 areas of the business life. In this study, its ranking version was used, which has a destimulant character and takes values from 1 to 190.

2. Wealth, but depicted more comprehensively than in purely economic terms. Therefore, indicators that take into account also non-economic factors were used: the Legatum Prosperity Index (Simkins, Peterson, 2016) and the Social Progress Index (Beslerova, Dzurickova, 2014). The Legatum Prosperity Index is a destimulant. The Social Progress Index is a stimulant taking values from 0 to 100 .

3. Gender/sexual equality. Here, the focus is on the situation of women and sexual minorities. To evaluate the situation of the former, the Gender Development Index (GDI) was used (Pollert, 2003), and of the former the Human Rights Situation of LGBTI (van der Veur, 2016). The Gender Development Index is a nominant in which the value of 1 means an equal situation of both genders; the lower the value, the worse the situation of women than of men; the higher, the better the situation of women than of men. This index directly measures the gender gap by presenting the female Human Development Index (HDI) as a percentage of the male HDI. The Human Rights Situation of LGBTI is a stimulant taking values from 0 to $100 \%$, where $0 \%$ means "gross violations of human rights, discrimination", while 100\% means "respect of human rights, full equality".

The social situation can be measured in a number of ways, and the indicators used for calculations partly determine the obtained results. Therefore, synthetic indicators were focused on, as they provide a more comprehensive overview of the situation, rather than individual variables. Of course, there are many indicators, and their selection for this analysis is partly subjective. In addition, some indicators are partly interrelated.

The spatial scope of the study includes European post-Communist countries, including whole Russia. However, Bosnia and Herzegovina and Kosovo were partially excluded from the analysis due to the lack of some statistics.

The time range of the study mainly covers 2016 . Even if there is 2017 next to the names of some indicators, the data used for their calculations most often come from a year earlier, e.g. data in Doing Business 2017 are current as of June 1, 2016. The statistics used in the paper come from websites of particular indices, and are shown in the sources under the maps.

Commonly used statistical methods were applied in the paper: to analyse the differentiation, the coefficient of variation (CV) was applied; for spatial autocorrelation analysis, Moran's $I$ statistic was used (when giving weights in the 
spatial weight matrix, rows were standardized to the value of one); to break down the analysed indicators, the method of Hellwig's critical distance was used. In the summary, the Pearson correlation coefficient (PCC), Perkal's index, and cluster analysis (Ward's method, Euclidean distance) were used. In calculations using cluster analysis, standardised variables were applied. A more complex procedure was used to calculate Perkal's index. For it to take the form of a destimulant, variables (except for the Gender Development Index) were standardized and then the World Press Freedom Index, Doing Business, and the Legatum Prosperity Index were left without change. In the case of the Human Rights Situation of LGBTI and the Social Progress Index, the obtained values were additionally multiplied by -1 . Because the Gender Development Index is a nominant, the applied procedure used was different: even before standardization, the variable values for each country were converted in such a way that they were calculated as the absolute value of the difference between 1.000 and the initial value of the indicator and only then were the new values standardized.

\section{Analysis}

In the analysed group of countries, the level of freedom of expression measured by the World Press Freedom Index (2017) took values from 13.6 in Estonia to 52.4 in Belarus and was very diverse, as evidenced by a relatively high value of the coefficient of variation amounting to $32.2 \%$. There is a very clear division of European post-communist countries into two groups: Russia and Belarus with its very adverse situation and the remaining countries with a good or average situation. At a closer scrutiny, five groups were identified: Estonia, Slovakia, the Czech Republic and Latvia, with very high freedom of expression (13.6-18.6); Slovenia with high freedom (21.7); and being on the opposite side Russia with low freedom (49.5) and Belarus with very low freedom (52.4). Other countries were categorised in a very large group with average freedom of the press (24.5-35.7).

Looking at the analysed phenomenon in spatial terms, its low spatial concentration is found (Moran's I statistic was only 0.04). This is confirmed by analysis of Map 1, which shows that there are two clusters of countries with a good situation (Estonia and Latvia on the one hand, and the Czech Republic, Slovakia and Slovenia on the other), one with a very bad situation (Russia and Belarus) separated by a belt of countries with an average situation. Undoubtedly, we can talk about the success of Estonia and Latvia in terms of freedom of expression, because these are the post-Soviet countries, while the other states of the former USSR are clearly characterised by low freedom of the press.

In terms of the level of economic freedom measured by the Doing Business (2017) ranking, countries of the analysed group took positions from 11 in Macedonia to 86 in Bosnia and Herzegovina. In addition, it was also highly 
differentiated ( $\mathrm{CV}$ was as much as $45.9 \%$ ). Similarly to the previous index, also here there is a clear division of the analysed countries into two groups. At a closer analysis, there are three single-element groups of countries with very disadvantageous conditions of economic freedom: Albania $\left(65^{\text {th }}\right.$ position), Ukraine $\left(76^{\text {th }}\right)$ and Bosnia-Herzegovina $\left(86^{\text {th }}\right)$. The remaining countries are characterised by good (Macedonia, Estonia, Lithuania, Latvia; 11-19) or average conditions (the remaining countries; 27-51).

Analysing the Doing Business ranking in spatial terms, no distinct spatial regularities can be observed (Moran's $I$ statistic amounted only to 0.14). Looking at Map 2, one can only state again that a relatively good situation is in countries of the Baltic Assembly, which should be considered their great success in the process of reforms.

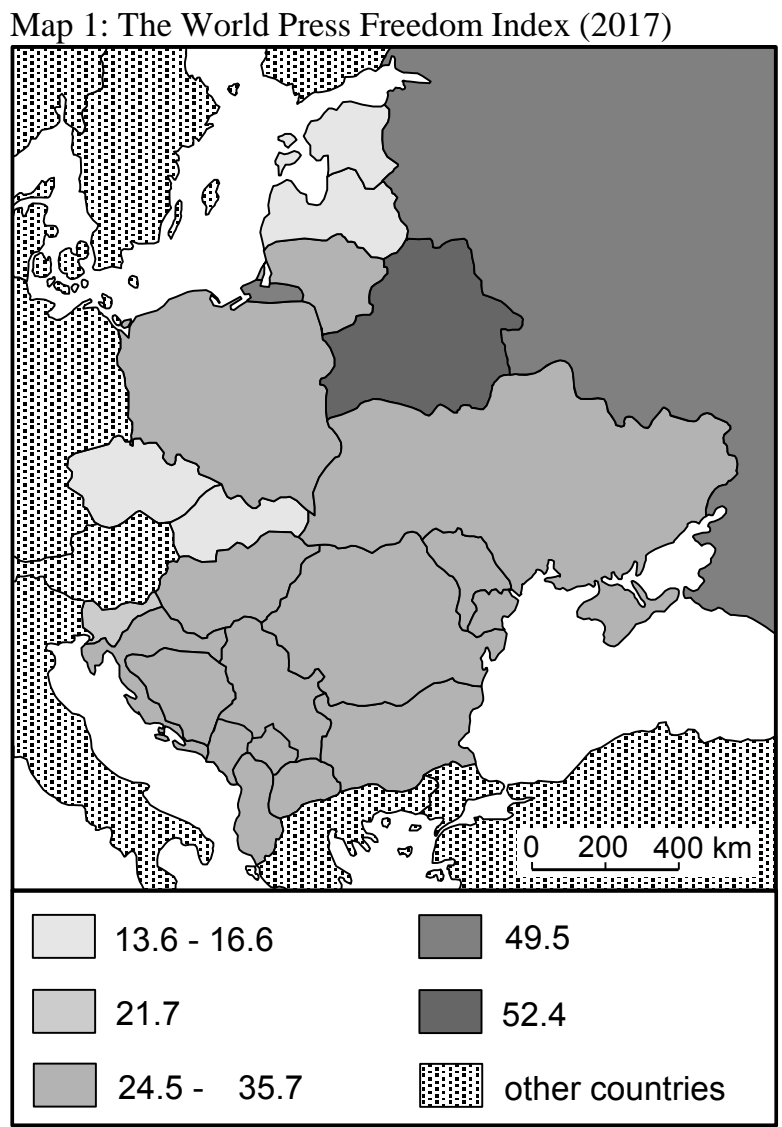

Source: 2017 World Press Freedom Index 


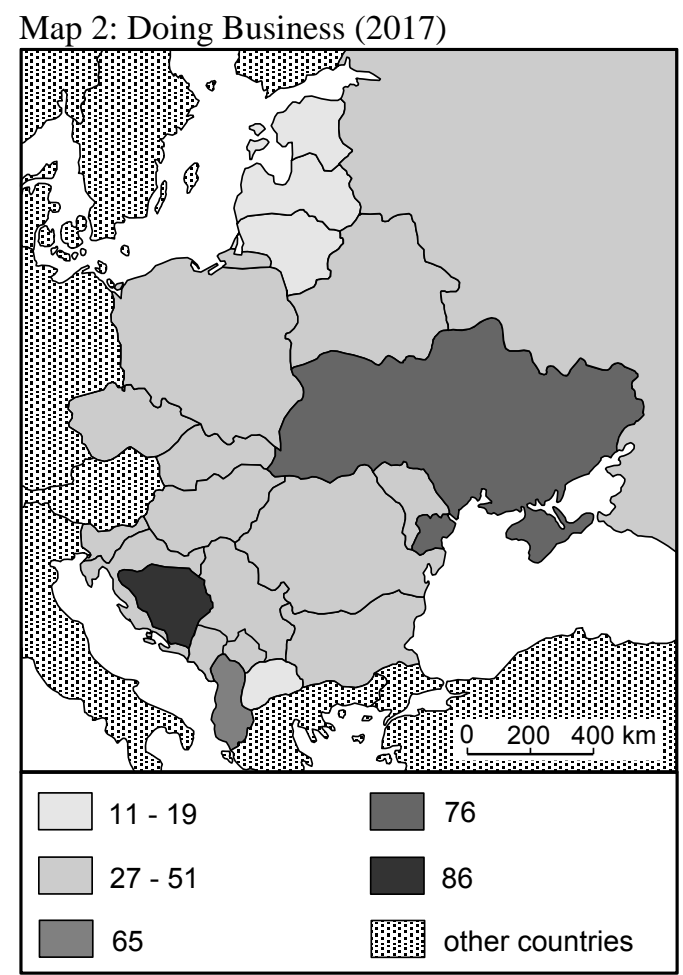

Source: Doing Business 2017

Due to lack of data for the Legatum Prosperity Index (2017), Kosovo as well as Bosnia and Herzegovina were excluded from the analysis. The remaining countries, in terms of the conditions and the quality of life measured by this indicator, take positions from 21 in Slovenia to 112 in Ukraine and were highly differentiated (CV was as high as $48.3 \%$ ). Looking at spatial differentiation of the analysed situation, again we can see a clear division of the studied countries into two groups (Map 3). The first one, with a good and average situation (positions from 21 to 58 in the world) comprises all post-communist countries that are currently members of the European Union, together with Macedonia and Serbia. But these two countries take the last places in this group. The other countries belong to four groups: Montenegro (65) and post-Soviet Belarus, Moldova, Russia (95-101) and Ukraine (112). Mainly due to the existence of two non-contiguous clusters of countries with a relatively worse situation of the population (the countries of the former Yugoslavia plus Albania and the countries of the former USSR without the Baltic Assembly), Moran's I statistics reached a rather low value $(0.15)$. 


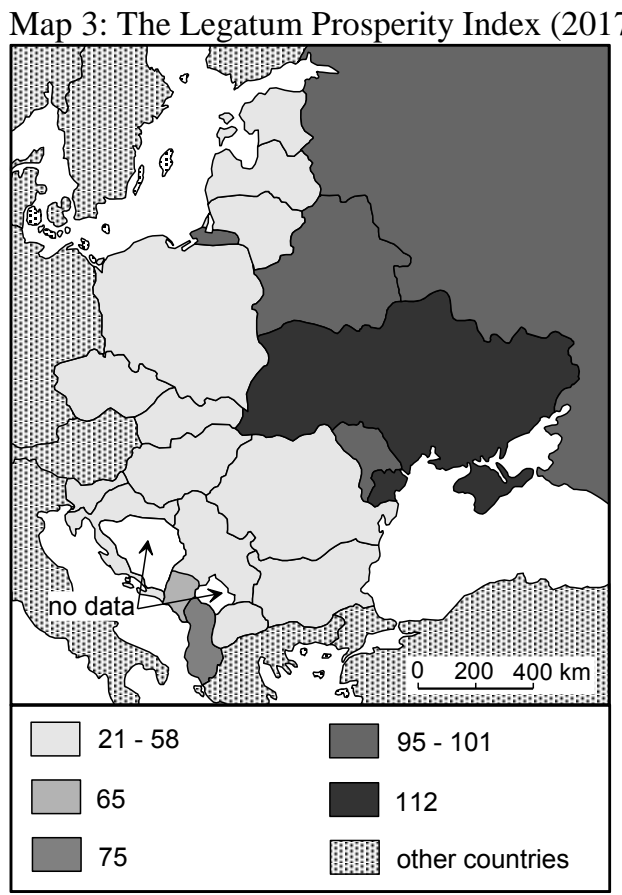

Source: The Legatum Prosperity Index 2017

Differentiation of the conditions and the quality of citizens' lives looks slightly different when they are measured by the Social Progress Index (2017). However, the analysis here does not cover Kosovo and Bosnia and Herzegovina, due to a lack of data. The best situation was recorded in Slovenia (84.3), immediately followed by the Czech Republic (84.2). The worst situation was in Moldova (66.3), and the differentiation of the conditions and quality of life of the population was much lower than in the case of the previous index, since the coefficient of variation amounted only to $7.6 \%$. The analysed states have been divided into four groups. A relatively very good situation of the population was recorded in Slovenia, the Czech Republic and Estonia (83.0-84.3), a good one in Slovakia, Poland, Latvia, Lithuania, Croatia, and Hungary (77.3-80.02), an average one in Serbia, Bulgaria, and Romania (73.4-74.4). Except for Serbia, these three groups comprised only the EU countries. The remaining states fell in the fourth group, with a bad situation (66.3-71.0).

Analysing the Social Progress Index in spatial terms (Map 4), we see the arrangement of two belts running from the north-east to the south-west. The first one, with a better situation, begins in Estonia and ends in Croatia. The second, with a worse situation, runs from Russia and Belarus to Albania (yet inside this belt 
there are countries with a little better situation than the others: Romania, Bulgaria, and Serbia). Due to such a belt-like arrangement of countries with a similar situation, Moran's $I$ statistic reached a value of 0.24 .

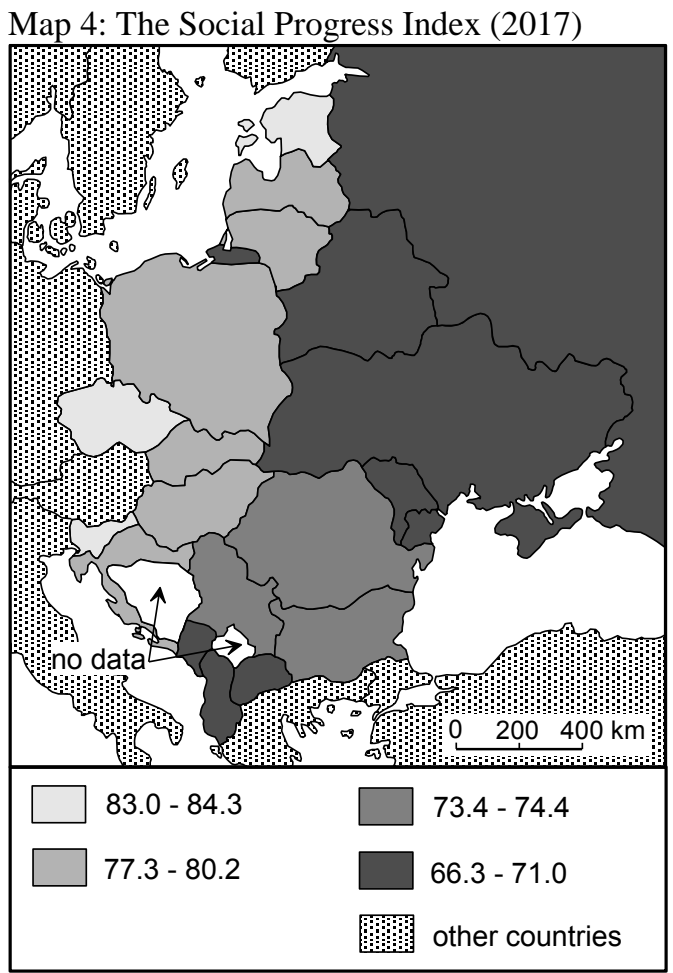

Source: Porter et al., 2017

Looking at the situation of women in 2015 in comparison to men, measured by the Gender Development Index, we see that there are both countries in which their situation is worse (Bosnia and Herzegovina being the worst - 0.923) and better (the best: Lithuania \& Estonia, both - 1.032), and the situation in the countries is little differentiated ( $\mathrm{CV}$ is only 2.8\%). For this reason, GDI is a nominant; unlike in the case of other indicators, a breakdown into equal brackets was applied. Thus, a relatively worst situation of women in comparison to men (GDI: 0.925-0.954) characterises Bosnia and Herzegovina and Macedonia, and a bad one (GDI: 0.955-0.984) Albania, Serbia, the Czech Republic, and Bulgaria. By contrast, a relatively better situation of women than men (GDI: 1.015-1.044) is in Russia, Belarus, Latvia, Estonia, and Lithuania. Other countries have a relative equality between both genders (GDI: 0.985-1.014). 
In spatial terms (Map 5), we see that a relatively worse situation of women in comparison to men was mainly in the Balkans; the opposite one was in most of the former Soviet Union countries. Unsurprisingly, Moran's I statistic had the value as high as 0.48 .

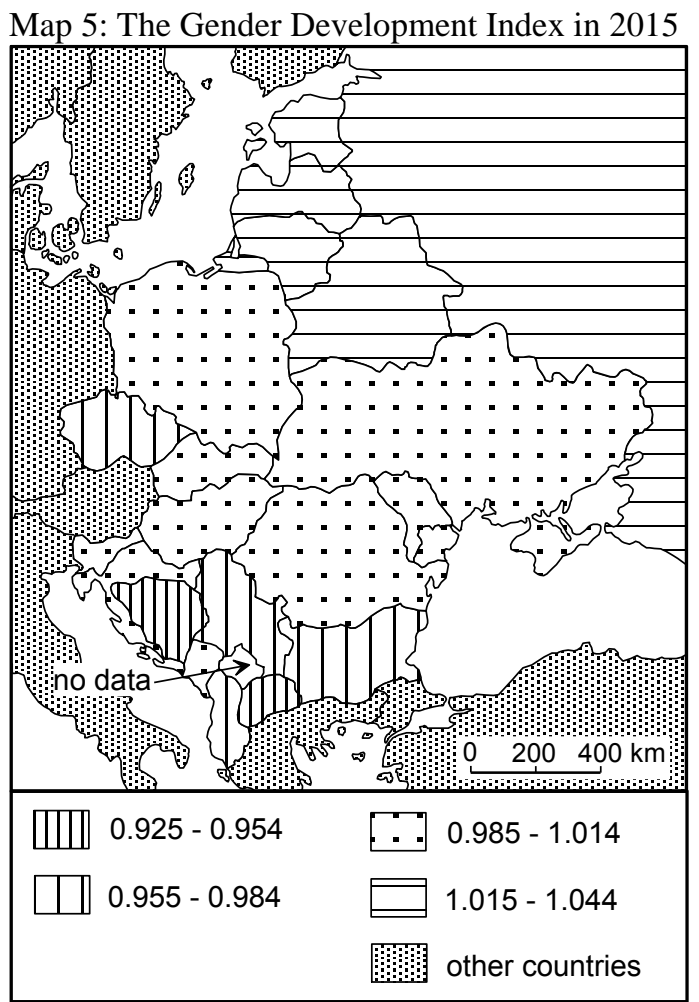

Source: Human..., 2016

The level of the Human Rights Situation of Lesbian, Gay, Bisexual, Trans and Intersex people (2017) in the studied group of countries had values from just $6 \%$ in Russia to $62 \%$ in Croatia and was highly varied (the CV value reached as much as $47.4 \%$ ). As a result, as many as six groups of countries were distinguished. A relatively very good situation prevailed in Croatia (62\%), a good one in Hungary and Slovenia (44\%-45\%), an average one in Montenegro (39\%) and Slovakia, the Czech Rep., Kosovo, Serbia, Bosnia and Herzegovina, Albania, Estonia (28\%-33\%). LGBTI people could enjoy little freedom in Moldova, Belarus, Macedonia, Lithuania, Latvia, Poland, Ukraine, Romania, and Bulgaria $(13 \%-23 \%)$ and very little in Russia (6\%). 
Analysing the Human Rights Situation of Lesbian, Gay, Bisexual, Trans and Intersex people in spatial terms (Map 6), we see clear spatial regularities: the best situations were recorded in the south-west part of the analysed area. The farther to the east, the worse the situation of LGBTI people. It is, therefore, no wonder that Moran's $I$ statistic reached the value of as much as 0.54 ).

Map 6: Indicator the Human Rights Situation of LGBTI (2017)

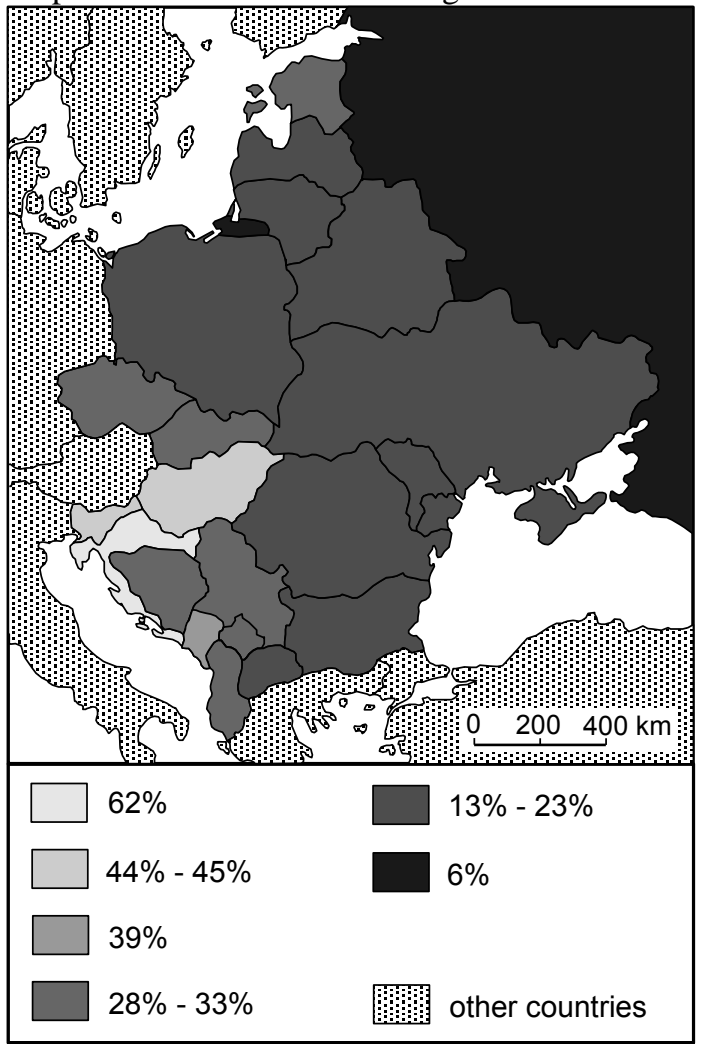

Source: May 2017. Reflecting ..., 2017

\section{Synthesis and conclusion}

The results of a study based on Perkal's index and cluster analysis are presented in Fig. 7. It follows that, in terms of the quality of the social situation in 2016, European post-communist countries can be divided into three groups. However, in terms of the relationship between the factors shaping this situation, there are two groups in which two subgroups can still be distinguished. 
Map 7: Synthetic assessment of the social situation in 2016

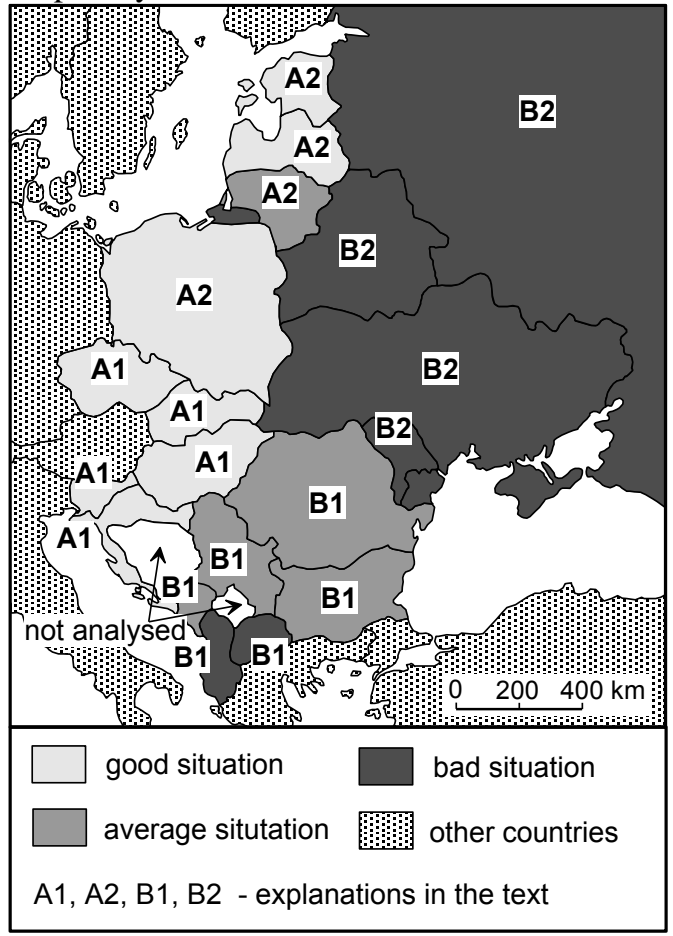

Source: own study.

A relatively favourable social situation existed in countries being members of the European Union (except for Lithuania, Bulgaria, and Romania). These countries (plus Lithuania) also belonged to the same group (labelled as A in Map 7), whose common characteristic was a very beneficial social situation in terms of wealth (measured by the Legatum Prosperity Index and the Social Progress Index). However, what differentiated them between the southern part, which comprised Slovenia, Croatia, Hungary, the Czech Rep., and Slovakia (labelled as A1), and the northern one (labelled as A2), which comprised Poland, Lithuania (in part), Latvia, and Estonia - is much more favourable situation of sexual minorities (measured by the Human Rights Situation of LGBT) in the countries classified in group A1.

Quite in contrast are the countries of the former USSR (without the Baltic Assembly) and Albania and Macedonia. They have been analysed together with countries with average situations (without Lithuania). These two groups of countries have been fully included in category B, characterized by low prosperity (measured by the Social Progress Index). What differentiates between them into the "Balkan" part, comprising Albania, Macedonia and partly Montenegro, Serbia, 
Bulgaria, and Romania (labelled as B1), and the post-Soviet part (labelled as B2), comprising Ukraine, Moldova, Belarus, and Russia, is a much more favourable situation of women (measured by the Gender Development Index) in the countries classified in group B1.

It can, therefore, be argued that the main factor for grouping spatially European post-communist countries is the conditions and the quality of their citizens' lives. The situation of women and the attitude to LGBTI is a complementary factor. On the other hand, issues related to civil liberties have less potential for spatial grouping, although the impact of the freedom of the press partly coincides with the conditions and the quality of the citizens' lives.

An interesting issue is the influence of history on the current diversity in the social situation in the analysed area, and it is not only the question of the degree of repressiveness of the Communist regimes (Anisimow, 2017), but also the influence of factors stemming from older history, such as the period of the formation of national identity (Wandycz, 2001), the influence of the dominant religion (Mazower, 2002) or opposition in the system: own statehood - occupiers' influence (Roszkowski, 2015). However, elaboration on the development of this idea requires separate research using other methods.

\section{References}

2017 WORLD PRESS FREEDOM INDEX. [online]. Reporters Without Borders. Paris, 2017 [cit. 2018-07-11]. Available at: 〈https://rsf.org/en/ranking/2017>.

ANISIMOW, J. 2017. Historia Rosji. Od Ruryka do Putina. Ludzie, daty, wydarzenia. Warszawa: Inicjał Andrzej Palacz, 2017. 457 p. ISBN 978-83-6406607-8.

BEDNAROVA, P. - LABOUTKOVA, S. 2013. Easy of Doing Business and Globalization linkages between both in developed market economies and developing countries. In $7^{\text {th }}$ International days of statistics and economics. Slany: MELANDRIUM, 2013. ISBN 978-80-86175-87-4, pp. 88-98.

BESLEROVA, S. - DZURICKOVA, J. 2014. Quality of life measurements in EU countries. In Procedia Economics and Finance. ISSN 2212-5671, 2014, vol. 12, pp. 37-47.

BEYME VON, K. 1996. Transition to Democracy in Eastern Europe. London: Palgrave Macmillan UK, 1996. 186 p. ISBN 978-0-230-37433-1.

Doing Business 2017. Equal Opportunity for All. [online]. Washington: The World Bank, 2017. 356 p. [cit. 2018-07-13] Available at: <http://www.doingbusiness.org/ /media/WBG/DoingBusiness/Documents/Ann ual-Reports/English/DB17-Report.pdf>. ISSN 1729-2638.

GIANNONE, D. - DE FRUTOS, R. 2016. Measuring Freedom of Information: Issues and Opportunities from an Expert Survey. In International Journal of Communication. ISSN 1932-8036, 2016, vol. 10, pp. 589-619. 
HAVRYLYSHYN, O. 2007. Fifteen Years of Transformation in the PostCommunist World. Rapid Reformers Outperformed Gradualists. [online]. Washington: CATO Institute, 2007. 20 p. [cit. 2018-07-03] Available at: $<$ https://object.cato.org/pubs/dpa/DPA4.pdf > .

HUMAN DEVELOPMENT REPORT 2016. Human Development for Everyone. [online]. New York: United Nations Development Programme, 2016. 286 p. [cit. 2018-07-16] Available at: <http://hdr.undp.org/sites/default/files/2016_ human_development_report.pdf>. ISSN 0969-4501.

JANUŠAUSKIENE, D. 2008. Post-Communist Democratization: Explaining the Differences. In Political Transformation and Changing Identities in Central and Eastern Europe. Washington: The Council for Research in Values and Philosophy, 2008. ISBN 978-1-56518-246-2, pp. 131-154.

KOLLMORGEN, R. 2013. Theories of Postcommunist Transformation. Approaches, Debates, and Problems of Theory Building in the Second Decade of Research. In Studies of Transition States and Societes. ISSN 1736-8758, 2013, vol. 5, no. 2, pp. 88-105.

MAY 2017. Reflecting the legal and policy human rights situation of lesbian, gay, bisexual, trans and intersex (LGBTI) people in Europe. [online]. Brussels: ILGA-EUROPE, 2017. 1 p. [cit. 2018-07-16]. Available at: <https://www.ilgaeurope.org/sites/default/files/Attachments/rainbow_europe_map_2017.pdf $>$.

MAZOWER, M. 2002. The Balkans: A Short History. New York: Random House, 2002. 240 p. ISBN 978-0-8129-6621-3.

NORKUS, Z. 2012. On Baltic Slovenia and Adriatic Lithuania. A Qualitative Comparative Analysis of Patterns in Post-Communist Transformation. Vilnius: Apostrofa, 2012. 375 p. ISBN 978-9955-605-68-3.

NOUINOU, S. - RAZAFIMAMPIANINA, R. M. - REGRAGUI, B DOUKKALI, A. S. 2015. Big Data: Measuring How Information Technology Can Improve the Economic Growth and Better Life. In Proceedings of the 2015 5th World Congress on Information and Communication Technologies (WICT). New York: IEEE, 2015. ISBN 978-1-4673-8712-5, pp. 152-159.

PINHEIRO-ALVES, R. - ZAMBUJAL-OLIVEIRA, J. 2012. The Ease of Doing Business Index as a tool for investment location decisions. In Economics Letters. ISSN 0165-1765, 2012, vol. 117, no. 1, pp. 66-70.

POLLERT, A. 2003. Women, work and equal opportunities in post-Communist transition. In Work Employment and Society. ISSN 0950-0170, 2003, vol. 17, no. 2, pp. 331-357.

PORTER, M. E. - STERN, S. - GREEN, M. 2017. Social Progress Index 2017. In Social Progress Imperative [online]. 2017 [cit. 2018-07-12]. Available at: <http://www.socialprogressimperative.org/wp-content/uploads/2017/06/Eng lish-2017-Social-Progress-Index-Findings-Report.pdf > .

ROSZKOWSKI, W. 2015. East Central Europe. A concise history. Warsaw: Wydawnictwo ISP PAN, 2015. 531 p. ISBN 978-83-64091-48-3. 
SIMKINS, T. J. - PETERSON, M. 2016. Assessing the Value of a Societal-Level Sustainability Index for Macromarketing Research. In Journal of Macromarketing. ISSN 0276-1467, 2016, vol. 36, no. 1, pp. 78-95.

THE LEGATUM PROSPERITY INDEX 2017. [online]. London: Legatum Institute, 2017. 64 p. [cit. 2018-07-12] Available at: <https://prosperitysite.s3accelerate.amazonaws.com/3515/1187/1128/Legatum_Prosperity_Index_2017. pdf >. ISBN 978-1-911125-30-3.

VAN DER VEUR, D. 2016. The human rights situation among LGBTI individuals in Europe and its health consequences. In European Journal of Public Health. ISSN 1101-1262, 2016, vol. 26, p. 223.

WANDYCZ, P. S. 2001. The Price of Freedom. A History of East Central Europe from the Middle Ages to the Present. London, New York: Routledge, 2001. 323 p. ISBN 0-203-41740-2.

associate prof. dr hab. Tomasz Michalski

Department of Regional Development Geography

University of Gdańsk

J. Bażyńskiego 4, 80-309 Gdańsk, Poland

e-mail: tomasz.michalski@ug.edu.pl

\section{dr Tomasz Wiskulski}

Department of Tourism and Recreation Management

Gdansk University of Physical Education and Sport

K. Górskiego 1, 80-336 Gdańsk, Poland

e-mail: tomasz.wiskulski@awf.gda.pl 